Pakistan Journal of Social Research

ISSN 2710-3129 (P) 2710-3137 (O)

Vol. 3, No. 2, June 2021, pp. 55-65, doi.org/10.52567/pjsr.v3i02.203

www.pjsr.com.pk

\title{
PASHTO POETRY AND MILITANCY IN KHYBER PAKHTUNKHWA AFTER 9/11: THEMATIC ANALYSIS OF PASHTO POETRY IN RESISTING MILITANCY
}

\author{
Nadeem Ahmad \\ PhD Scholar, Department of Anthropology, Quaid I Azam University, Islamabad, Pakistan \\ Nadeem.takkar4@gmail.com
}

Ikram Badshah

Assistant Professor, Department of Anthropology, Quaid I Azam University, Islamabad, Pakistan ikram@qau.edu.pk

\begin{abstract}
Abdul Qayum Khan
Lecturer, Kohat University of Science and Technology, Khyber Pakhtunkhwa, Pakistan. qayumkhan2006@hotmail.com
\end{abstract}

\begin{abstract}
The present study sheds light on Pashto or Pakhto Poetry and Militancy in Khyber Pakhtunkhwa after 9/11. The fieldwork for this study was conducted in the Peshawar district of Khyber Pakhtunkhwa, Pakistan, from December 2020 to April 2021. Findings of this research are based on data collected in district Peshawar of Khyber Pakhtunkhwa. Data for this paper was collected through participant observations, in-depth interviews, Focused Group Discussions (FGDs), and informal discussions with poets, literary people, audience of poetry gatherings, and academicians. Furthermore, the collected data is analyzed through thematic analysis. The works on 'culture alternatives' of social movements of Guha and Laclau and 'weapons of the weak' by Scott have been consulted for the theoretical framework of the current research. Data collected from various sources reveals that Pashto poetry is influenced by different factors. These includes cross boarder interaction and interaction with neighboring languages, invasions by outsiders, resistances of Pakhtun/Pashtuns to invaders and socio-religious movements where different themes and genres were introduced to Pashto poetry. After 9/11, Pashto poetry played pivotal role in countering militancy, terrorism and so called 'war on terrorism.' Pashto poetry internalized themes of Peace, Condemnation of War, Nationalism, and Resilience along with others -in which few were borrowed from the $20^{\text {th }}$ century-into the social fabric of the Pakhtun society. These themes in Pashto poetry entail potentials to counter violence in KhyberPakhtunkhwa caused by militancy, terrorism and 'war on terrorism'.
\end{abstract}

Keywords: Pakhtuns, Pashto Poetry, Themes, Resistance, Militancy, Khyber Pakhtunkhwa

\section{INTRODUCTION}

For the past twenty years since 9/11, most of the region inhabited by the Pakhtuns in Pakistanthat includes the province of Khyber Pakhtunkhwa, Ex-FATA ${ }^{1}$ and part of the Baluchistan province - has been engulfed by militancy, terrorism, and the so-called war on terrorism. This area borders Afghanistan, which was invaded by the USSR in 1979 and then by America in 2001. In the former case, Pakistan supported Mujahedeen/ Taliban and US against USSR. In the latter case, Pakistan supported America against Taliban after 9/11.

Since Pakistan sided with the US in the war against terrorism, the militants as a retaliation started to attack any person associated with or collaborating with the government. They started attacking police stations, military installations, security forces' convoys, courts and marketplaces, and political gatherings in the Pakhtun region. Bomb blasts, explosive devices' denotation, suicide bombings, beheading and kidnaping in broad daylight became the norm of the day. They successfully challenged the state writ in Swat, Ex-FATA and in various other localities. They

\footnotetext{
${ }^{1}$ The seven tribal agencies namely South Waziristan, North Waziristan, Kurram, Bajaur, Mohmand, Khyber, and Orakzai and now the new districts of Khyber Pakhtunkhwa.
} 
controlled areas of Ex-FATA and Swat district of Khyber Pakhtunkhwa by force and imposed a conservative and rigid brand of Islam on locals.

Pakistani Arm forces launched a full fledge military operation against these militants in all the afore-mentioned areas. Many places in these areas were targeted from the air as they were hideouts of key militant commanders. Civilian population suffered gravely because of these operations and resulted in the flight of local people into nearby surrounding districts. There was a warlike situation in the area. Military check posts and barricades, barbwire and tanks, security forces' convoys and restricted mobilization became the norm of the day. Violence became more intense and frequent. The locals of these areas became Internally Displaced Persons (IDPs), abandoned their homes, and turned towards urban and militant free rural areas to seek shelter because of the military operations started against the militants.

Along with government officials and installation the militants started targeting artists, poets, singers, teachers, and shrines as a potential threat to their ideology (Hussain K. , 2013). These forums and sites however did not succumb to militant rule and ideology because they are largely moderate and modern in outlook and thought. Scores of actors and artists were killed, and other sites were bombed by militants. Countering this ideological violence, the Pakistani state started building up its own narrative, underpinned by violence: Musharraf's vision of Pakistan as a 'moderate and liberal' state, there are 'good Taliban' and 'bad Taliban', and the bad Taliban are conspiring with the enemies of Pakistan, etc. In this narrative-building war, militants and Pakistani state followed combative competition in the production of literature, video messages, electronic and print media, pamphlets, interviews, etc. Various academic writers like (Rana, 2004); (Hussain Z. , 2008); (Fair, 2014), as well as the media added to this literature about violence. Such literature as a whole conveniently ignored literature on non-violence - (Shah, 2007); (Banerjee, 2000); (Tendulkar, 1967) — and the philosophy and the legacy of non-violence of Khudai Khidmatgar Movement (KKM) founded by Khan Abdul Ghaffar Khan aka Bacha Khan against British colonialism in India with support-base in the Pakhtun region. this movement brought about a splendid revolution in culture, art, poetry, and social lives which resulted in new life for the Pathans (Kurtz, 2011).

This research takes into an account that how violence in the context of $9 / 11$ has been countered through non-violence philosophy, legacy and works inspired from KKM and Abdul Ghaffar Khan in first instance. Since various fields upheld this principle and legacy in the Pakhtun region, however, this study takes culture as a domain of study with focus on the role played out by artists, singers, and poets in resisting militancy and terrorism and its narrative through their works after $9 / 11$ in KP. With this focus in mind, this research aims to add a 'different' strand to the literature mentioned earlier on one hand, and highlights the service done by artists, singers, and poets in combating violence through their peaceful means of works. This research highlights the historical role of the Pashto poetry in the face of all adversaries such as foreign invaders, militants' religious ideologies, historical and political epochs, and socially important events. How for these social forces have influenced the themes and nature of the Pashto poetry in time and space? The main purpose of this research is to investigate and analyze how themes in Pashto poetry counters militancy, terrorism, and 'war on terrorism' in the Pakhtun region of Pakistan after 9/11?

\section{THEORETICAL FRAMEWORK}

This research falls in the domain of social movements where different forms of art and culture work as a stimulant to cause peoples resistance. These culture and art forms are known as the 'cultural alternative' in social movements, which bring political science and anthropology together. There is a very less contribution to cultural side or what is considered as 'Boasian perspective' of the social movement, which create the resistant's space in society through means of art and culture. Social movements employ a variety of culture and art forms like borrowing the powerful symbols, reforming, and remodeling the existing culture for creating new culture by arguing that culture cannot be viewed as a tool or merely symbolic form alone (Vinthagen, 2012). The construction and promotion of the narrative of historical identity through prose writing in 
rural India by peasant movements and the role of kinship ties and ethnicity in social movements of Latin America are the examples of cultural alternatives (Guha R. , 1988); (Laclau E. , 1986). These cultural alternatives are called as strategies of nonviolence by Gene Sharp (2013) and these strategies and are examined by Richard B. Gregg. (2018).

Poetry have played a role in shaping an alternative to the violent and oppressive regimes as well as to the dominant discourses. Pashto poetry is no exception of it, and it is used in literary forums and spaces where the Pakhtuns resisted state power historically as well as discrimination within society. Moreover, it comes in the domains of what James C Scott's called Weapons of the weak in his much known and celebrated book. The crux of the Scott's formulation of resistance is that open resistance has consequences as it leads to severe punishment and disciplinary actions. Therefore, to keep the resistance alive and active, the resisters must play with the suppression and domination. On the one hand they escape the suppression and on the other hand keep they keep on to resistance. It is the level of oppression that shapes the level of resistance (Scott, 2008, p. 292). Scott's work Weapons of the weak in Pakhtuns case is advanced by Khan et al (2020), and argued that, a group of the Pakhtuns comprising the younger generation and mostly students who moved to cities for education or due to "war on terror" have organized and developed different spaces what the authors called Informal Spaces (Usman Khan, 2020). In these informal spaces the Pakhtuns who are critical on the Pakistan's state role especially in the context of 9/11, constructed an alternative narrative to the state and provided a foundation and literary support to the ongoing resistance for the restoration of the Pakhtun's cultural, historical, and political identity as well as problematized and critically engaged the "war on terror" narrative in the Pakhtun's region. Considering the above theoretical engagement and framework, this study critically engages and analyses poetry as a form of resistance that challenges the national and international agenda, and role of imposing a kind of war that raged and reshaped the Pakhtun region overwhelmingly. In response, the Pakhtun poets and literary critics challenged the dominant discourse of "war on terror" through poetry. They also represented their cultural, political, and historical identity in the form of poetry to keep their genesis in the form of cultural production.

\section{METHODOLOGY}

Fieldwork was conducted in the historical and significant city of Peshawar, the capital city of Khyber Pakhtunkhwa. Peshawar is located on historical route, Khyber Pass, between Central and South Asia. Currently the city hosts important state buildings, privately owned businesses, and commercial centers of the province. Being a hub of the state machinery, it remained an important area for political and social activism for centuries. Political parties, literary societies and public and private educational institutions research centers, publication houses, museums, archives, and bookshops remained the identity of the city. In other words, the centrality of Peshawar as a cultural and political hub of Pakhtuns made it to play exceptional role in the decades-long violence and crisis. That was the reason that Peshawar remained a stronghold of the non-violent movement and its legacy. The second reason was that the city also remained the target of the militants' attacks in the past eighteen years after 9/11. Third reason was that the militancy has been resisted in Peshawar by the adherents of the non-violence philosophy.

Researchers and literary people arranged various poetry and literary gatherings, seminars and book launching ceremonies and academic activities concerning Pashto poetry in the Department of Pashto, Pashto Academy of University of Peshawar, Mafkoora Research Centre, and Bacha Khan Research Centre may particularly be mentioned. The respondents for this research were poets, audience of the poetry gatherings and other scholars. Total of thirty (30) respondents were selected through random sampling and purposive sampling. Reason for using random sampling is that we meet a lot of poets and audience in the field where we use to select the respondents randomly. While in some cases the poets, audience and experts are selected through purposive sampling because of their special understanding and rich knowledge of the area. Actual names and descriptions of the respondents are being used with their consent. During the research, data was collected through participant observation, in-depth interviews using 
interview guide and focused group discussions (FGDs). For the convenience of the respondents, the interviews and FGDs were conducted in the local Pashto language and then transcribed into English by the researchers.

Poetry included in this paper is selected based on the themes from recitation of poetry in live sermons during fieldwork. These types of gatherings are called mushaira (s) where poets one by one comes on the stage to share their new composition of verses with audience and other poets for receiving appreciation and disseminating their views to public. Some couplets were also collected from the poets and experts during individual interviews and focus group discussions. The collected poetry was translated into English by the researchers using simple verse to convey the message of the poetry for the readers' understanding. Some sources of the Pashto literature were also used in the researchers' own words in English language, where it is needed to be discussed in the paper. During interviews and FGDs, vignette method was used to discern poetry in detail and was linked to the nature of findings and exploration. The couplets of poetry, used in this paper, were narrated before the respondents during interviews and informal discussions, and they were asked to shed light on the themes and meanings expressed in these couplets. The vignette method was helpful for the respondents to express their understanding of the poetry and in investigating the dominant themes as well as historical roots of the themes in Pashto poetry. The method also enriched the findings of the research through investigating hidden meanings in the poetry which Pakhtun poets use as weapons.

Furthermore, the collected data was thematically analyzed using the technique of thematic analysis. All the data went through coding process where data was organized through line-by-line coding in the first stage of analysis. After the process of coding, the data was divided based on themes and road themes were collected from the data. In the next step the data was put under certain themes according to connectivity of the broader themes with the data. The method of thematic analysis was helpful in developing themes in the data and interconnectivity of themes which helped in constructing theoretical argument.

\section{Pashto Poetry in time and Space}

Pashto language sees different eras where socio-economic situations, cross-border interaction with the Persian, Indian and Turkic languages, invasions, and resistance of the Pakhtuns to invaders and religious and political movements affect the Pashto language (Hanifi, 2013); (Habibi, 2005, p. 530). This effect is in terms of text and script as well as themes and genres of oral tradition, poetry, and prose of the Pashto language. In this line of debate, the Pashto poetry and literature is basically categorized in three Dawr (eras) known as Larghoni Dawr (ancient era), Classikee or Myanzani Dawr (classic or middle era) and Jadeed Dawr (modern era) (Zaiwar, 2018, p. 43). Each Dawr is then sub-categorized into different school of thought known as Maktab (Scool) also called as Sabak (Style), which is associated with a poet, an era, a movement, or an area. These Maktabona (Plural of Maktab) are known as Larghoni Maktab (ancient school), Rokhani Maktab (Roshanite School), Khushal Maktab (Khushal Khan School), Rahman Maktab (Rahman Baba School), Hindi Maktab (Hindi School), Ulasi Maktab (Folk School) and Nawi Maktab (Modern School) (Rishteen, 1988).

The first part of Larghonai Dawr is about those poets and literary figures whose written record has not been found and they are only discussed in poetry or in folklore, which compose the second part of Larghonai Dawr. In the second part of Larghonai Dawr, there are poets who have used simple Pashto language in their poetry and the themes of their poetry are mostly love, beauty, aesthetics, glorification of tribal chiefs, etc. Most of the poetry written in the second part of Larghonai Dawr contains genres like Qaseeda, Marsiya and Poem (Zaiwar, 2018, p. 43). Some folk genres are also claimed to be from Larghonai Dawr of Pashto poetry, transmitted orally for generations. Though there are different opinions of experts on these folk genres of Larghonai Dawr (Rishteen, 1988, pp. 7-8).

The second era of Pashto poetry, which is called Classikee Adab or Myanzani Dawr, starts with the Mughal invasion of the Indian subcontinent. This era of Pashto poetry has seen two major resistance movements; Rokhani Tehreek (Roshanite Movement) of Bayazid Ansari also 
known as Pir Rokhan and Khushal Khan Khattak's revalry with Mughul Emperor Aurangzaib (Rishteen, 1988, pp. 9-10) ${ }^{2}$. The poetry of the Rokhani Tehreek (Roshanite Movement) is called as the first era of Pashto poetry which has many gains including introducing the Pakhtuns to reading and writing as well as making Pashto literature and poetry works for their active resistance against Mughal rule. Themes of the poetry of the Roshanite Movement are based on glorification of war and bravery along with mysticism (Rishteen, 1988, p. 11). Khushal Khan Khattak's poetry contain themes of Pakhtun nationalism and unity, along with themes of Sufism, romanticism, and societal problems. Khushal Khan Khattak was not only a poet but also a warrior, leader of his tribe, which make his character unique as compared to other poets of classical era. That is why his poetry mostly depicts armed struggle to defend and protect his people (Rishteen, 1988, p. 14) (Pakhtunyar, 2021). This is very much evident from his poetry as at one stage he writes; "Da Afghan pah nang me otarrala toora / Nangyalay da zamanay Khushal Khattak yam" ("I girded my sword in the honor of the Afghan (nation) / I am the daring Khushal Khattak of this era") (Pakhtunyar, 2021).

The age of Khushal Khan Khattak and his contemporaries, poets after Khushal Khan Khattak like his sons and grandsons, i.e., Ashraf Khan Khattak, Gohar Khan Khattak, and poets like Rahman Baba, Hameed Baba, Kazim Khan Shida and Ali Khan introduced the Pashto literature to new themes and genres. In this period Pashto poetry adopted new themes related to idealism, romanticism, aesthetics, and realism (Rishteen, 1988, p. 24). Though except Khushal Khan Khattak, the classical era's poets did not give much attention to discuss social evils, their causes, and their solution. One can find very few examples of classical poetry in which poets have highlighted social evils. As Rahman Baba says: "Pa sabab da zalemano hakemano / Kor aw gor aw Pekhawar dre warra yaw dee" ("Because of the deeds of wicked potentates / Our home, grave and city (Peshawar) are equally unsafe) (Zalal, 2021). The couplet of Rahman Baba depicts the condition of the city of Peshawar when the Mughals were sovereigns (Rishteen, 1988, p. 17). However, there are very few examples of poetry where resistance has been put to oppression and repression.

In the $19^{\text {th }}$ century, when the British were in control of the Indian subcontinent, the Pakhtuns (now inhabiting in parts of Afghanistan and the newly merged districts of Pakistan) faced an invasion from the Crown as an attempt to capture the Pakhtun land. Three wars, generally known as the Anglo- Afghan wars, were fought between the British Crown's Indian forces and the Pakhtuns in 1839, 1878, and 1919. During this era of conflict and turmoil, there was no significant contribution to the Pashto writings, either in verse or prose. (Hanifi, 2013) (Jan W. , 2021). In those years, Pashto folklore reached its zenith, where people sang about the glory of wars and victories of their heroes, their stories of aesthetics, romance, and love in different genres like Charbaita, Tappa, Loba and Sandara (Gairas, 2008) (Jan W. , 2021) . After the beginning of the $20^{\text {th }}$ century, the Pakhtun society witnessed a new age in terms of politics and literature.

The freedom movements of the $20^{\text {th }}$ century against the British colonialism like the Khudai Khidmatgar Movement (KKM), introduced Pashto poetry to themes like peace, nonviolence, nationalism, coexistence, politics, resistance, problems, suffering, and social evils. (Zalal, 2021). Along with other movements and literary works, the rise of KKM brought about a paradigm shift in Pashto literature (Bawar, 2021). Kurtz noted KKM as "a new life for the Pathans," which created "a splendid revolution in their art, culture, poetry, and social life" (Kurtz, 2011). The KKM was started by Bacha Khan in 1928 in the Utmanzai village of the erstwhile NWFP. It was a socially committed anti-colonial nationalist movement of the Pakhtuns (Shah, 2007). It not only organized the Pakhtuns along with modern lines of politics as an outward political strategy against the British Raj, but at the same it also worked as a non-violent social reform strategy, which aimed at reforming the Pakhtun society. The KKM was considered a paramount threat to colonial power and the social fabrication by the British. It worked as an

\footnotetext{
${ }^{2}$ Rokhani and Rokhani is also called as Roshan and Roshani in soft variety of Pashto language.
} 
indispensable force for forging unity among the Pakhtuns to wage the non-violent political struggle effectively. The Political struggle against the British colonialism, social reforms agenda, cultural and literary promotion, and production in the Pakhtun society have been the major goals that defined most of the history of KKM's long struggle (Bala, 2013).

To further the cause of the movement, Bacha Khan started a monthly journal in the Pashto language called The Pakhtun in 1928 (Jan F. , 1993). The journal consisted of essays on social and political subjects, which was published from the Utmanzai village ${ }^{3}$. The Pakhtun was printed in Amritsar in its nascent days (Amir O. , 1986). The main purpose of the journal was to highlight the core problems of the Pakhtun society to discuss the contemporary issues, and to promote and develop Pashto language and literature to enable the Pakhtuns to meet the futuristic demands of scientific and literary inquiry. Along with 'the Pakhtun' journal, the KKM played a vital role in the organization and unity of the writers and artists through literary and poetry gatherings as well as recitation of poetry in political gatherings. The KKM gave a platform to the poets for discussing social issues, unity, and organization of the Pakhtun society through their writings. The KKM was working as a guiding force for the poets and writers to highlight the social issues in their poetry and writings (Khalil, 2021). Bacha Khan correctly appreciated and recognized that Pashto literature, poets, and literate class of the society can easily mobilize the marginalized Pakhtun society to raise the voice against the unjust British rule and the problems arising from it (Amin, 2021).

The poets started writing for the unity of the Pakhtuns through discussing the social problems and social evils of the Pakhtun society and their united resistance to the British imperialism. Literary people, and especially poets, changed the perception of the Pakhtuns from being an all-time belligerent people (Gherati qaam- the superior image of the Pakhtuns as a nation) to a peaceful, tolerant, and believer of coexistence (Buneri, Pakistan Poetry Fight Backs, 2012). As Ghani Khan writes: "Jang la de Mansoor rawan, Toup ao na tapang lari / Na da toro praq lari, Na da zgharo shrang lari" ("Mansoor (referring to Bacha Khan the freedom fighter) is going to war without any cannon and mortar; Neither he owns a shining sword nor any valuable armor ") ${ }^{4}$. It is the contribution of the KKM that if we look at the Pashto poetry today, there will be a couplet of nationalism and highlighting of social problems of society in every poem (Hussain K. , 2021). This couplet of Pashto poetry best expresses the effect of the KKM on Pashto poetry: "Saleema sam de ka ghazal shar'e tha / Lag paki zikar da khpal qaam kawa" ("O Saleem! Put your ghazal in accordance with the doctrines (Pakhtunwali; the Pakhtun code of conduct); Do mention your nation in it"). Tariq explained this poetry couplet as "it is necessary to write about the problems and issues of the Pakhtun society." It has become the principle of Pashto poetry to discuss social evils and social problems in a more simplistic way (Pakhtunyar, 2021).

Poets like Fazal Mahmood Makhfi, Shad Muhammad Maigay, Wali Muhammad Tufan and Fazal Rahim Saqi are called as first generation of the KKM legacy and were prominent in KKM's struggle against British colonialism. In the second-generation poets like, Qalandar Mohmand, Ajmal Khattak, Ghani Khan and many others were prominent for the literary contributions as well for awareness in Pakhtun society through their poetic and literary essence. The second generation of the poets struggled for democracy and equal rights for different ethnicities, classes, and sects. These poets also write about the dictatorships in Pakistan as well as resisted violence from state and non-state actors. While the third generation of Pakhtuns poets were those who watch the current wave of militancy on Pakhtun land. In those, Rehmat Shah Sail, Sahib Shah Sabir, Dr. Israr and Ali Akbar Siyal among other are prominent in this stage (Mahmood, 2012). The poets and literary people of the third generation of Khudai Khidmatgar Movement resisted this militancy and terrorism through non-violent means on different levels.

\footnotetext{
${ }^{3}$ Bacha Khan was its first editor and Atta Ullah was the publisher.

${ }^{4}$ Mansoor is a symbolic figure in Muslim literature who resisted the dogma of clergies.
} 


\section{Themes of Resistance in the aftermath of 9/11}

After 9/11 the security situation in KP including the then FATA deteriorated when America declared war on terror. The result of the War on Terror was the rise of extremism in the region, leading to emergence of extremists in many areas. Taliban started killing the innocent people especially those who opposed their stance. The ideas and narrative of non-violence legacy were hindering their way and acted as a barrier to the violent ways used by extremists to achieve their goals (Buneri, 2021). The legacy of Non-violence resisted militancy and extremism from the beginning. The KKM and its legacy were very critical even in Russia-Afghan war in the 1980s. They openly criticized the project of Afghan Jihad as well as the indulgence of the Pakistani state in Afghan Jihad (Raza, 2021). A respondents quoted words of Bacha Khan in the time of Afghan Jihad against USSR, that: "The seeds of Mujahideen which you people are sowing will transform into a forest one day, and be aware, a fire in the forest cannot be controlled" (Yousafzai, 2021). Though there was no space for the narrative of the KKM legacy neither in media nor in academia.

Along with other forms of culture and art the poets and literary people were on forefront of those who were resisting militancy. The Pakhtun poets used different platforms for disseminating their poetry in the masses, which included live poetry gatherings, publishing books, publishing magazines, and the use of print and electronic media as prominent sources (Arman, 2021). They were successful in creating space for their poetry in public, and it was the reason that themes like 'condemnation of war' and 'peace' were not only dominant in poetry but also in other ways of life. The Pakhtun poets also praised the attitude of masses towards poetry, as a respondent quoted poetry couplet of Izhar Ullah Izhar: "Mala haghi qaam da zrra pa tal ke zaye rakari / Las ke che janana nh qalam aw nh kitab lari" ("I'm adored by a nation that / possess neither pen nor a book") (Izhar, p. 58). The poetry couplet shows the love and respect of the Pakhtuns for their poets. The Pakhtuns may not have pen and books, but they will love and respect poets (Bawar, 2021).

Pashto poetry produced during the last two decades mainly focuses on the themes of 'peace,' 'condemnation of war,' 'Resilience'. These themes were presented on nationalistic sprit in Pashto poetry. As a respondent quoted that while reading or listening Pashto poetry, one can find themes of 'condemnation of war', 'quest for peace and resilience with nationalistic spirit. Themes like peace and condemnation of war were introduced in the last twenty years. While some of the themes like nonviolence, resilience and nationalism were transformed from the twentieth century's poetry. Each of the themes used to construct alternative narrative for countering narrative of violence and militancy (Iqbal, 2021). This paper is focused mainly on three themes of including 'condemnation of war', 'peace', and 'ressiliance' which are dominant in Pashto poetry after 9/11.

\section{Condemnation of War}

The theme of 'condemnation of war' was very dominant in Pashto poetry in the last two decades. The theme was used to condemn all those people, institutions, and states, who were supporters of militancy, terrorism, or war on terrorism in one way or the other. While talking on militancy and war as well as the role of religious leaders who are said to have been supporters and promoters of militancy in the region, a respondent quoted these couplets of poetry: "Ay da jumat ao da mandar muhafizano waorai / Bamona ma jorawai, tenkoona mh jorawai / Da jang na sa jorregi, jangoona ma jorawai"; ("Beware the leaders of mosques and temples / Don't make bombs and tanks / War is a curse, don't make wars") (Ahmad, 2021). In these couplets the poet condemns war, the arms, and bombs and the role of those who ideologically support and promote war. The Pakhtun poets, audience of poetry, and intelligentsia are critical of those who are involved in supporting militancy either physically or ideologically. Talking about those who physically or ideologically supported militancy, an audience/respondent in a poetry gathering shared his views by quoting a couplet of Sahib Shah Sabir: "Da sro lambo da ghargharo da zora na di khabar I Daa sok che Jang ghwari da jang da zora na di khabar" ("Thee are ignorant of the wrath of blazing fire / Thee who wage war, are ignorant of its power of obliteration") (Manerwal, 2021). This couplet of poetry on the one hand talks about the consequences, fatalities, and devastation of 
war, and condemns the supporters and promoters of war (Muhammad, 2021). Talking about the consequences of war and militancy, the famous poet Aziz Manerwal shared a couplet of his poetry: "Jang qatil day, insanan wajalay kegi / Da chaa wror, da chaa janan wajalay kegi" ("War is a beast, it swallows every being; Be it somebody's brother or beloved) (Manerwal, 2021). In post $9 / 11$ poetry, the theme of the 'condemnation of war' is very dominant, where poets try to condemn war and those who support or promote war (Khan Z. , 2021).

In Pashto poetry, the poets condemn militancy and war not only because of the fatalities, but they also show their love for the land, and everything attached to it. As one of the respondents shared a couplet while talking about his land: "Ma darta tol umar da gulono khaar wayali de I Kala me perzo shi pa bamono Pekhawara" ("I have always praised you as my beloved, O the city of flowers; O my Peshawar! / How come I could tolerate that you are bombed") (Bawar, 2021)5. In this couplet, the respondent expresses his grief about Peshawar being bombed and be a center stage of militants' bomb blasts and target killings in the last two decades after 9/11. In Pashto poetry and literature as well as in folk traditions, the city of Peshawar is called as the city of flowers. During the last two decades, the Pakhtun poets called Peshawar as city of flowers to show their love for the city and to remind the people the beauty of the city, which will help them to work for peace. In another couplet a poet also says: "Zama watan kho da sandaro aw naghmo watan de / Hum pakay gul kegi aw hum pakay bulbula kegi" ("My land is the land of songs and melodies / Both flowers, and nightingale can be found here"). In this couplet the poet is calling the Pakhtun land as the land of beauty, songs and melodies which is now facing war and militancy (Zalal, 2021).

The Pakhtun poets also call militancy, terrorism, and war on terrorism in KhyberPakhtunkhwa, as an imposed war. They reject the narratives which of shows militancy as the product of the Pakhtun culture and call the militancy as a project of others. Calling militancy as other's project, Aziz Manerwal shared these couplets of Sahib Shah Sabir:

"Pa chaman ke ka guloona ka azghi mri /

Kho zama da kor khayast zma sparli mri /

Daa me nura badbakhti na da nu sa da /

Pah pradi jang ke zama da kor zmari mree"

("If it is flower or the thorn which are being destroyed /

These all are the beauties of my house, dying /

What should I call it if not my bad luck? /

The brave men of my home dying in a war of others"). (Manerwal, 2021).

In these couplets of poetry, the poet remembers the militancy, which have made a war like situation in the Pakhtun region, where violence is indiscriminately destroying everything. For the poet, the natural beauty of the land, which includes flowers and gardens as well as youngsters, are important, so he remembers both in his poetry couplets. The poet also called the militancy in the Pakhtun region as an imposed project by outsiders, so he calls it as 'imposed war.'

\section{Poetry of Peace}

The theme of 'Peace' also remains dominant in Pashto poetry in the last two decades after 9/11. Reason behind the theme of 'Peace' is that peace remains the most prior demand of the people in the last twenty years because of militancy, which created a war like situation in the Pakhtun region. People ask for peace through many ways, especially in protests, wall chalking, political gatherings and in public conversations (Khan H. , 2021). In this line of debate a young poet shared these couplets of poetry written by Khalil Ur Rahman Khalil: "Likam yaw dasey rang kalaam da aman / Che warkawi hamesh peghaam da aman" ("I am going to compose such a poetry of peace / That is evident to give a message of peace, always"). The respondent added that the Pakhtun poets are using their pen and the rest of their energies for bringing peace to their land. He further added another couplet: "Pa sar da zmakay ra khwaro Pukhtano / Pasai che ukrru

\footnotetext{
${ }^{5}$ The couplet is produced before $9 / 11$ though it remains very popular in the context of post 9/11 violence in Pakhtun region of Pakistan when Peshawar was on hit list of militants.
} 
intezam da aman" ("O Pakhtuns! from every corner of the world / Let us be united to bring eternal peace to the land"). In this couplet the poet calls to his fellow Pakhtuns, inhabiting in every corner of the world, to get united and work for bringing peace to their land (Pakhtunyar, 2021). The poet writes about peace in their poetry, but they also know that only writing about it is not enough. We also need to work hard to acquire it. That is why they call the Pakhtuns from every corner of the world to work for achieving peace. While talking on the theme of peace in Pashto poetry, a respondent also added that the theme of peace is the continuity of the nonviolence legacy of the Khudai Khidmatgar Movement. It was nonviolent struggle of Bacha Khan which created space for themes like peace in Pakhtun society. It is now a common saying among nationalistic circles that nonviolence creates and promote peace and violence create and promote hate. The respondent also added a couplet of Amjad Shahzad to support his argument: "Zama da qaam bachi la har sarri wasla warkary / Yaw Bacha Khan warla da aman falsafa warkary" "Everyone has given a gun in hand to the youth of my nation / It was Bacha Khan only who gave them the philosophy of Peace"). In this couplet, the poet has explained the role of Bacha Khan, who was the only man to give the philosophy of non-violence to the Pakhtuns. In conceptual meaning the couplet means that everyone, was it the native or the foreigner, has brought war to the Pakhtun region. It was the Khudai Khidmatgar Movement of Bacha Khan, which gave the philosophy of peace and nonviolence to the Pakhtuns. One of the respondents also shared that due to absence of peace in the Pakhtun land, the youngsters could not imagine the real peace and seek refuge in intoxicating drugs. The respondent shared a couplet of Jalal Khalil: "Naa poha di da aman aw wahdat na khabar na di / Sukoon zama da qaam bachi la banga raobasi" - ("They are unaware of the fruits of unity and peace / The youth of my nation is trying to find peace in weeds"). This couplet, on the one hand, describes the ignorance of the Pakhtuns about unity, which can bring about peace to their land, and on the other hand, the attainment of peace of mind, or tranquility through means of various intoxicants, which is injurious to both health and the cultural fabric of the society. It also meant as a source of awareness for the youth, where the poet is calling out to them to unite and struggle for real and long lasting peace (Pakhtunyar, 2021) (Bawar, 2021).

\section{Poetry of Resilience}

It is known that militancy and terrorism spread fear in the masses, which in turn make them apolitical. In this case, the poetry worked not only as a source of awareness but also as a source of resilience. Poetry of resilience, on the one hand, helps the masses to know different aspects of militancy, and to make sure that the public show their resilience and fight to counter it, on the other hand (Pakhtunyar, 2021). The resilience in poetry counters many phenomena, which is the byproduct of militancy and terrorism i.e., hopelessness, fear, terror, and the extermination of dreams. Pashto poetry worked as a source of courage, hope, entertainment, and awareness through themes of resilience. Talking about the theme of resilience in Pashto poetry, a young poet recalled: "Ay wakhta kh qatil da har arman me ye kho sa? I Bya hum pa wacho shondo me naghma da zindagai" ("O wicked time! What if you are the killer of my dreams / There are songs of life on my dry lips"). In this couplet, the poet laments about the time and space being the killer of his dreams, and yet he tries to spread the message of hope and love for life through singing songs of the beauty of life (Khalil, 2021). Talking about the messages described in the abovementioned couplet, a respondent stated: "poetry can explain many things in one couplet which couldn't be explained in long speeches and discussions. One can see messages of shattering of dreams, poverty, singing songs about the glory of life, and blaming time and space in only one couplet" (Pakhtunyar, 2021). Jalal is also of the thought that in the times of militancy and terrorism, it is natural that people will sing about the beauty of life, hope, and love. He added a couplet of his poetry: "Ranra da takhayul ba me zyategi khamakha / Wajood che me tor tam de aw lamba da zindagi" ("It is pertinent that the light of my ingenuity will intensify / When life is ablaze and my whole body is ingulfed") (Khalil, 2021). The poet discusses things metaphorically, where he takes light of imagination as metaphor for creativity and flames and darkness as metaphor for violence and insecurity in the society. In other words, the poet compares his poetry 
to light in his life and the social conditions to the flames of ravaging fire, and his poetry as a creative force against the depleted condition of society. The couplet gives hope and resilience against fears and terrors prevalent in the Pakhtun society (Pakhtunyar, 2021).

Pakhtun poets condemn violence produced by militancy, terrorism, and so-called war on terrorism. They also give message of peace, nonviolence, and resilience to counter the militancy, terrorism, and so-called war on terrorism. The Pakhtun poet call the violent situation of the Pakhtun society as proxy war between international powers. As a respondent quoted couplet of a young female poet:

$$
\begin{gathered}
\text { "Aey da Hamza aw Ghani Khan bachiya / } \\
\text { Pasa rawekh sha da soor oor marr krra / } \\
\text { Dagha che sta pa sar tayar walar de / } \\
\text { Da narriwal jang dagha shor marr krra / } \\
\text { Gora ka da zali ouda patay shwe / } \\
\text { Grana da bya kh rata ta patay shwe" } \\
\text { ("O son of Hamza and Ghani Khan! / } \\
\text { Wake up and kill the ravaging fire / } \\
\text { That what is lurking on your head / } \\
\text { End this world war and the chaos / } \\
\text { What if you didn't do anything to stop it / } \\
\text { You and the like will perish") }
\end{gathered}
$$

In the above-mentioned couplet, the poet mentions the proxy war in the Pakhtun region and tries to aware the Pakhtuns about the consequences of being caught during international wars. The poet gives reference of the Pakhtun elders to remind history to the people, which is full of bravery and sacrifices of those elders for the land and its people. She requests her people to wake up and kill the fire on their land and call the war like situation as imposed from outsiders. The poet is also warning the Pakhtuns that if they failed to counter and resist the war on their land, they will face the question of survival this time (Khan N. , 2021). The couplet shows the struggle of the Pakhtuns poets against proxy wars on the Pakhtun region.

\section{CONCLUSION}

Pashto poetry is not free from the time and space factor as the objective conditions of history and the present has impacts its thought and theme and its other associated parts like genre, etc. In these objective conditions, violence, and war from Alexander the Great to the war on terror, and the movement of Roshanites and post -Roshanites and KKM responded in its own way intellectually as well as politically to conditions. Though literature about Pakhhtun, its culture and region are largely foreign in authorship, however, it is filled with biases, master perspective and has present Pakhtun as a barbaric and violent in almost all aspects of lives particularly in the war against terror. Contrary to that, this region has remained a bastion of non-violence and it has its own peaceful and nonviolent roles and life to live. These roles and history have been documented also by various scholars; however, their numbers are not many. However, out of these various roles, this research investigated only the role of poets with reference to the themes of resistance, condemnation of war, peace, and resilience they have taken up in their poetry. For the poet, its weapon is poetry and the bullets of weapon for him is the themes of the poetry. These themes of peace and nonviolence in the poetry of the various poets as documented above helped on one hand to present the true picture of the Pakhtun's history and culture to the world at large and, on other hand, countered militancy and militant discourse, ideology, and appeal.

\section{REFERENCES}

Ahmad, D. (2021, January 22). Personal Interview. (N. Ahmad, Interviewer)

Amir, O. (1985). History of Press in NWFP. Peshawar: Free Lance Research Publications.

Arman, S. A. (2021, March 5). Personal Interview. (N. Takkar, Interviewer)

Bala, S. (2013). Waging the Nonviolence: Reflections on the History Writing of the Pashtun Nonviolent Movement. Peace and Change, 131-154. 
Bawar, A. (2021, January 28). Personal Interview. (N. Ahmad, Interviewer)

Benerjee, M. (2000). The Pathan Unarmed; Oposition and Memory in the NWFP. London: Oxford University Press.

Buneri, S. (2012, January). Pakistan Poetry Fight Backs. Retrieved from Pulitzer Center on Crisis Reporting: http://pulitzercenter.org/reporting/afghanistan-pakistan-pashtun-resistance-poetrytaliban-secular-nationalist-shehzad-sail

Buneri, S. (2021, March 5). Personal Interview. (N. Ahmad, Interviewer)

Fair, C. (2014). Fighting to the End: The Pakistan Army's Way of War. New York: Oxford University Press.

Gairas, G. F. (2008). Da Merani Ulas Adeebat: Da Laro Pukhtano Adeebat (Literature of the Courages People: Literature of the Lar Pakhtuns). Peshawar: Danish Khparandoya Tolana (Danish Publishing Society).

Gregg, R. B. (2018). The Power of Nonviolence (2d rev. ed). Cambridge University Press.

Guha, R. (1988). Selected Subaltern Studies. New York: Exford University Press.

Habibi, A. H. (2005). Da Pukhto Adeebato Tareekh (History of Pashto Literature). Peshawar: Danish Khparandoya Tolana (Danish Publication Society).

Hanifi, S. M. (2013). A History of Linguistic Boundry Crossing within and around Pashto. In B. D. (Editors), Beyond Swat: History, Society and Economy along the Afghanistan-Pakistan Frontier (pp. 63-75). London: Hurst \& Co.

Hussain, K. (2013). The Militant Discourse: Religious Militancy in Pakistan. Islamabad: Narratives Publishers.

Hussain, K. (2021, February 7). Personal Interview. (N. Ahmad, Interviewer)

Hussain, Z. (2008). Frontline Pakistan: The Struggle with Militant Islam. New York: Colombia University Press.

Iqbal, A. (2021, March 28). Informal Discussion. (N. Ahmad, Interviewer)

Izhar, I. U. (2018). Zmaki Da Asman Rangona Rawri De (Earth has colors of the sky). Peshawar: Aeraf Printers.

Jan, F. (1993). Khudai Khidmatgar Movement in NWFP: Its Nature and Direction. Peshawar: Department of Pakistan Studies, University of Peshawar.

Jan, W. (2021, March 16). Personal Interview. (N. Ahmad, Interviewer)

Khalil, J. (2021, March 7). Personal Interview. (N. Ahmad, Interviewer)

Khan, H. (2021, February 3). Informal Discussion. (N. Ahmad, Interviewer)

Khan, N. (2021, January 23). Personal Interview. (N. Ahmad, Interviewer)

Kurtz, L. R. (2011). Peace Profile: Abdul Ghaffar Khan's Non Violent Jihad. Peace Review: A Journal Social Justice, 245-251.

Laclau, E. (1986). New Social Movements and the Plurality of the Social. In D. Slator, New Social Movements and the State in Latin America (pp. 27-42). Amsterdam: CEDLA.

Mahmood, N. (2012, January 29). Pashto Poetry: A Symbol of Resistance Throughout History. The News: International.

Manerwal, A. (2021, January 18). Personal Interview. (N. Ahmad, Interviewer)

Marwat, F. U. (2005). From Muhajir to Mujahid, Politics of War Through Aid: (A Case Study of Afghan Refugees in NWFP). Peshawar: Pakistan Study Center, Peshawar.

Muhammad, R. (2021, January 17). Informal Discussion. (N. Ahmad, Interviewer)

Pakhtunyar, T. (2021, February 20). Personal Interview. (N. Ahmad, Interviewer)

Rana, M. A. (2004). A to Z of Jihadi Organizations in Pakistan. Lahore: Mashal Book Publishers.

Raza, A. (2021, January 25). Personal Interview. (N. Ahmad, Interviewer)

Rishteen, S. U. (1988). Da Pukhto Adabi Maktabona (Schools of Pashto Literature). Peshawar: University Book Agency.z

Scott, J. C. (2008). Weapons of The Weak: Everyday Forms of Peasant Resistance. New Haven: Yale University Press.

Shah, S. W. (2007). North West Frontier Provience. Islamabad: NIHCR.

Sharp, G. (2013). How Nonviolent Struggle Works. Boston: Albert Einstein Institution.

Tendulkar, D. G. (1967). Abdul Ghaffar Khan: Faith is a Battle. Bombay: Gandhi Peace Foundation.

Usman Khan, Y. C. (2020). Reclaiming Pashtun Identity. Intervention.

Vinthagen, M. J. (2012). Nonviolent Resistance and Culture. Peace and Change, 444-470. 


\section{Ahmad, Badshah \& Khan}

Yousafzai, M. (2021, January 26). Personal Interview. (N. Ahmad, Interviewer)

Zaiwar, Z. U. (2018). Da Pukhto Adeebato Tareekh (Larghonai Dawra) (History of Pashto Literature: Ancient Era) (Second Edition). Nangarhar, Afghanistan: Momand Khparandoya Tolana (Momand Publication Society).

Zalal, S. (2021, February 25). Personal Interview. (N. Ahmad, Interviewer) 